Original Article

\title{
ANTIHYPERLIPIDEMIC EFFECT OF ETHANOLIC SEED EXTRACT OF CANAVALIA ENSIFORMIS (L) IN HIGH FAT DIET-STREPTOZOTOCIN INDUCED RATS
}

\section{K. ANITHA*, PUTHALAPATTU RAVIKUMAR YASHODA}

Department of Pharmacology, JNTU Ananthapuramu, Sree Vidyanikethan College of Pharmacy, A. Rangampet, Tirupati 517102 Chittoor District A. P. India

Email: kuttiappananitha@gmail.com

Received: 06 Aug 2018 Revised and Accepted: 04 Dec 2018

\section{ABSTRACT}

Objective: It was investigated to enlighten the phytochemical screening and antihyperlipidemic activity of seeds of Canavalia ensiformis (L.) in High fat diet Streptozotocin-induced diabetic rats.

Methods: The ethanolic seed extract of Canavalia ensiformis (EECE) at a dose of $400 \mathrm{mg} / \mathrm{kg}$ and $200 \mathrm{mg} / \mathrm{kg}$ was administered to diabetic rats. Simvastatin $(4 \mathrm{mg} / \mathrm{kg})$ is used as a standard drug.

Results: The statistics were assessed by using one way ANOVA followed by Dunnet's multiple comparison tests. To unfold the mechanism we studied all the biochemical parameters like Total cholesterol (TC), Triglycerides (TG), high-density lipoproteins (HDL), low-density lipoproteins (LDL) and histopathological examination of Liver tissue section. The ethanolic extracts of seeds of Canavalia ensiformis showed significant reduce of the level of cholesterol, triglycerides, LDL, VLDL and a significant increase in the serum level of HDL at $400 \mathrm{mg} / \mathrm{kg}$ rather than $200 \mathrm{mg} / \mathrm{kg}$.

Conclusion: Further the characterization and isolation of the constituents could be done to know the exact mechanism of hyperlipidemic activity. Statistical analysis of this screening method conforms that the proposed method is appropriate and it can be useful, gives the basic idea to the researcher who is working in an area like Antihyperlipidemic activity.

Keywords: Canavalia ensiformis, Simvastatin, High fat diet Streptozotocin, Cholesterol, Triglycerides, LDL, and HDL

(c) 2019 The Authors. Published by Innovare Academic Sciences Pvt Ltd. This is an open-access article under the CC BY license (http://creativecommons.org/licenses/by/4.0/) DOI: http://dx.doi.org/10.22159/ijpps.2019v11i1.28961

\section{INTRODUCTION}

Canavalia ensiformis family belonging to Leguminosae is climber that was distributed throughout India. Canavalia ensiformis synonyms are Canavalia ensiformis var. truncata Ricker and Dolichos gladiatus Jac. q. It is commonly known as jack bean and pig bean $[1,2]$. The genus Canavalia is distributed throughout tropical and subtropical regions. The woody perennial/biennial twinning shrubs, branches. Flowers purplish in axillary racemes. Fruit legume, thickened along the both the sutures, seeds 8-20 white or ivory [3]. The whole plant is used for fodder, although it cannot be used in fodder mixtures containing urea, since it contains large quantities of the enzyme urease, which liberates harmful ammonia from urea. The dry mature seeds are used as a foodstuff, but are not popular because of their unacceptable flavor and texture. According to "Bavaprakash" an ayurvedic write-up, awara is said to be slightly bitter but a palatable food, though it is not used as a drug, it is good for constipation and some other ailments [4]. The jack bean is a legume with a nitrogen-fixing ability; it would not be expected to need fertilizer nitrogen. Dietary fiber of the species of Canavalia ensiformis was considered to be an important legumes which contributes to health in various ways by reducing disease risks in coronary heart disease by lowering the serum cholesterol level by decreasing the absorption; reduce the colon cancer risk, by increasing the fecal bulk and thereby decreasing the concentration of carcinogens; improve glucose tolerance in diabetic subjects by slowing the release of glucose into the bloodstream $[5,6]$. Due to the high nutritional values, the seeds are used to feed cattle and the leaves are food for humans. It is quite resistant to changes in environmental conditions, insects, and microorganisms [7-9]. As a green manure, it was intercropped with cacao, coffee, and sugarcane. Young pods and immature seeds are used as vegetables.

The macro morphological features of the seeds of Canavalia ensiformis were depicted in fig. 1. In addition, these major compounds extracted from seeds of $C$. ensiformis have important pharmacological effects, thereby aiding in the understanding of the physiology of organisms and in the treatment of various pathologies. By considering all the facts the aim of the study was to unlock the antihyperlipidemic activity of the Canavalia ensiformis in High-fat diet Streptozotocin-induced model.

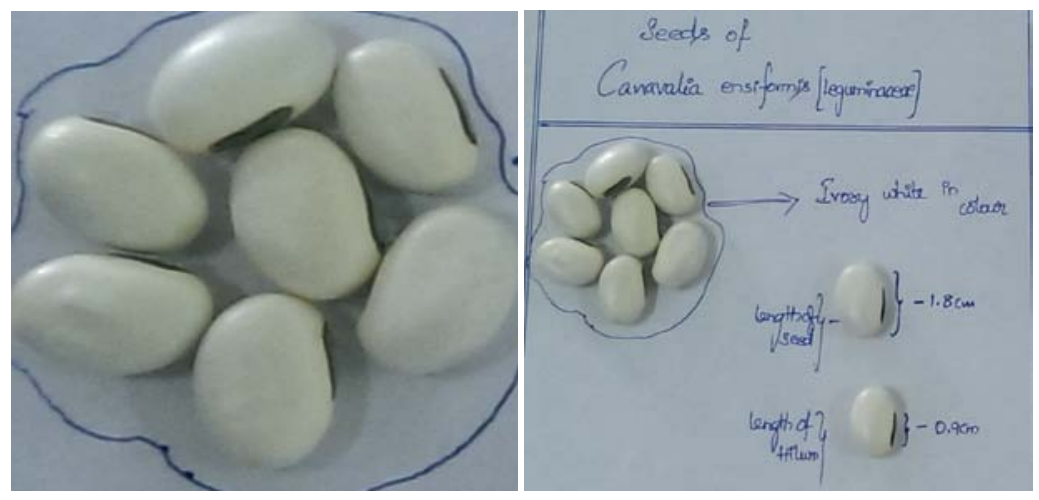

Fig. 1: Collection and macro morphological features of Canavalia ensiformis seeds 


\section{MATERIALS AND METHODS}

\section{Plant material and authentication}

Seeds of Canavalia ensiformis was collected in the month of November from Tirumala hills, Chittoor district of Andhra Pradesh and authenticated by Professor N. Yasodamma, Department of botany, Sri Venkateswara University, Tirupati, India and compared to that of the standard Herbarium SVUTY, department of botany with specimen voucher No: 129 collected by A. Job Roger Binny on $10^{\text {th }}$ June 2014 and preserved as Voucher Specimen No: KL-20.

\section{Chemicals and reagents}

Streptozotocin (STZ), Simvastatin and the biochemical estimation kits were procured from Aldrich sigma Ltd. Bangalore.

\section{Extraction}

Collected seeds were shade dried, powdered and that powdered crude substance 500 gm was taken and run in Soxhlet apparatus for $72 \mathrm{~h}$ with ethanol as a solvent respectively. The extract was obtained by concentrating in Rotary flask evaporator under reduced pressure at $65{ }^{\circ} \mathrm{C}$; yield was found to be $4.89 \%$ and stored in the desiccators for the further use $[10,11]$.

\section{Preliminary phytochemical screening}

EECE was subjected to Preliminary phytochemical screening for the detection of various phytoconstituents such as alkaloids, glycosides, saponins, flavonoids, tannins, phenolic compounds, triterpenoids, carbohydrates, proteins using standard procedures as per mentioned in Kokate and Harbone [12, 13].

\section{Experimental animals}

The albino Wister rats of either sex weighing between 150-200g were taken for the study which was procured and maintained in a well-ventilated room with 12:12 hour light/dark cycle in polypropylene cages. Standard pellet feed (Hindustan Lever Limited., Bangalore) and drinking water were provided ad libidum throughout the experimentation period. Rats were acclimatized to laboratory conditions one week prior to initiation of experiments [14]. Ethical Committee clearance was obtained from IAEC (Institutional Animal Ethical Committee) of CPCSEA (Committee for the Purpose of Control and Supervision of Experiments on Animals) and bearing SVCP/19/IAEC/2018.

\section{Acute toxicity studies}

As per OECD 423 guidelines the ethanolic seed extract of Canavalia ensiformis was administered to albino Wister rats by oral route starting from $5 \mathrm{mg} / \mathrm{kg}$ to $2000 \mathrm{mg} / \mathrm{kg}$. The animals were monitored for any changes continuously and observed for any lethality [14].

\section{Experimental design}

The rats were fed by Normal Standard Pellet (NSP) for the initial period of $2 \mathrm{~W}$ [15]. After $2 \mathrm{w}$ of dietary manipulation, the group of rats fed by HFD and was injected a dose of STZ $(45 \mathrm{mg} / \mathrm{kg}$ ), intraperitoneally (i.p.) except the respective control rats were given vehicle citrate buffer ( $\mathrm{pH} \mathrm{4.4)} \mathrm{in} \mathrm{a} \mathrm{dose} \mathrm{volume} \mathrm{of} 1 \mathrm{ml} / \mathrm{kg}$, i. p. The administration was continued for $3 \mathrm{w}$ and on $21^{\text {st }}$ day STZ $(45 \mathrm{~g} / \mathrm{kg})$ was administered and the fasting blood glucose was measured $3 \mathrm{~d}$ after the vehicle or STZ injection. 20\% glucose was administered after $4 \mathrm{~h}$ of STZ injection and ethanolic extract of Canavalia ensiformis low dose and high dose was continued for $21 \mathrm{~d}$ after STZ injection. The rats with the fasting blood glucose $2200 \mathrm{mg} / \mathrm{dl}$ were considered diabetic and selected for further pharmacological studies [16]. Group I: Normal Control rats were administered $0.1 \%$ CMC in saline daily (NC). Group II: Diabetic control rats were administered HFD+STZ (45 mg/kg). Group III: Diabetic control rats were administered HFD+STZ $(45 \mathrm{mg} / \mathrm{kg})$ and Standard drug Simvastatin $(4 \mathrm{mg} / \mathrm{kg})$. Group IV: Diabetic control rats were administered HFD+STZ $(45 \mathrm{mg} / \mathrm{kg})$ and ethanolic extract of C. ensiformis $[200$ $\mathrm{mg} / \mathrm{kg}$ per body weight (BW)]. Group V: Diabetic control rats were administered HFD+STZ $(45 \mathrm{mg} / \mathrm{kg})$ and ethanolic extract of $C$. ensiformis $[400 \mathrm{mg} / \mathrm{kg}$ per body weight (BW)]. Body weight was measured weekly. At the end of $21 \mathrm{~d}$ of treatment, the diets were removed from the cages $12 \mathrm{~h}$ before the animals were euthanized. Blood samples were collected by the retro-orbital method and centrifuged to obtain serum [17] after the collection of blood, the rats were euthanized, and liver was excised immediately, rinsed with phosphate buffer saline, and weighed. The samples were undergone for biochemical estimations and Liver, stored in $10 \%$ formalin solution for histopathological studies.

\section{Measurement of body weight of the rats}

Initial and final body weight of the rats was measured using the weighing machine and the data obtained was represented in the table 2 .

\section{Measurement of biochemical parameters}

Determination of the serum biochemical parameters such as the TC,TG, HDL, LDL, VLDL were measured using the commercially available standard kits $[18,19]$ according to the instructions and the results were calculated as per the formula and depicted in the table 3.

\section{Histopathological studies}

After inducing hyperlipidemic condition, rat from each group was anesthetized and liver was removed from the abdominal region of each rat and was excised quickly and fixed in $10 \%$ buffered-formaldehyde at room temperature. After dehydration using graded ethanol, pieces of tissues were embedded in paraffin, $5 \mu \mathrm{m}$ thick sections were cut by a rotator microtome and mounted on glass slides. Sections were then deparaffinized with xylene, counterstained with hematoxylin and eosin $[20,21]$. After the tissue sections were stained with hematoxylin and eosin and then viewed were examined using an Olympus BX51 microscope model U-LH100HG, and the results were shown in fig. 3-fig. 7. The hepatic damage was determined by counting the number of hepatocytes i.e., normal visible and also we should assess and analyze all the histopathological sections.

\section{Statistical analysis}

The statistical analysis was carried out using Instat Graph pad 3.6 software. All values were expressed as mean \pm SEM Data analysis was done by one-way ANOVA followed by Dunnett's multiple comparison tests. Difference level at $\mathrm{P}<0.05$ was considered as a statistically significant condition.

\section{RESULTS}

\section{Preliminary phytochemical analysis}

The Phytochemical Screening of ethanolic extracts of seeds of Canavalia ensiformis revealed the presence of flavonoids, phenolic acids, saponins, terpenoids, proteins and alkaloids, and results were represented in table 1 .

Table 1: Preliminary phytochemical screening

\begin{tabular}{lll}
\hline S. No. & Chemical tests & Inference \\
\hline 1. & Test for Carbohydrates & + \\
2. & Test for Alkaloids & - \\
3. & Test for Proteins & + \\
4. & Test for Glycosides & - \\
5. & Test for Flavanoids & + \\
6. & Test for terpenoids & + \\
7. & Test for Resins & - \\
8. & Test for Tannins & - \\
\hline
\end{tabular}

+indicates presence and-indicates the absence 


\section{Acute toxicity studies}

The body weight of the rats before and after EECE administration, also changes in skin, fur fall, eyes, and a sign of tremors, lethargy, motor activity, and behavior pattern were observed, and the desired dose was selected.

\section{Measurement of body weight of the rats}

Body weights of the rats were monitored on the initial and final day of the experimental period and data obtained were tabulated in table 2 .

\section{Antihyperlipidemic activity}

All the biochemical estimations of lipid serum levels such as TG, TC, HDL,LDL, VLDL was measured in all groups of rats and the values as follows. The serum levels of TG, TC, and LDL were increased, and HDL decreased in diabetic-induced rats compared to that of the control rats however in the treated groups the serum levels of the TG, TC, and LDL were decreased, HDL increased in standard and extract treated groups compared to that of the diabetic group rats. The serum values of TC, TG, LDL, VLDL was $162 \mathrm{mg} / \mathrm{kg}, 157 \mathrm{mg} / \mathrm{kg}$, $54 \mathrm{mg} / \mathrm{kg}, 31 \mathrm{mg} / \mathrm{kg}$ which indicates the increased level, decreased the level of HDL $20 \mathrm{mg} / \mathrm{kg}$ in diabetic-induced rats that depicts the hyperlipidemic condition. After the administration of Standard drug (Simvastatin $4 \mathrm{mg} / \mathrm{kg}$ ) the serum values of TC, TG, LDL, VLDL was $89 \mathrm{mg} / \mathrm{kg}, 90 \mathrm{mg} / \mathrm{kg}, 41 \mathrm{mg} / \mathrm{kg}, 16 \mathrm{mg} / \mathrm{kg}$ and increased level of HDL $30 \mathrm{mg} / \mathrm{kg}$ that shows the significance towards hyperlipidemic condition. In extract low dose $(200 \mathrm{mg} / \mathrm{kg})$, high dose $(400 \mathrm{mg} / \mathrm{kg}$ ) treated groups $92 \mathrm{mg} / \mathrm{kg}, 94 \mathrm{mg} / \mathrm{kg}, 38 \mathrm{mg} / \mathrm{kg}$, $28 \mathrm{mg} / \mathrm{kg}$ which indicates the decreased level, increased level of HDL $28 \mathrm{mg} / \mathrm{kg}$ that depicts the potential of high dose of ethanolic extract of seeds of Canavalia ensiformis. The serum levels of the control, diabetic and treated rats with EECE were tabulated as shown in the table 4.

Table 2: Effect of extract on body weights

\begin{tabular}{lllll}
\hline Groups & I & II & III & IV \\
\hline Initial weight $(\mathrm{g})$ & $222 \pm 2.24$ & $219 \pm 0.78$ & $220 \pm 1.32$ & $218 \pm 0.67$ \\
Final weight $(\mathrm{g})$ & $259 \pm 0.98$ & $168 \pm 1.2$ & $192 \pm 1.84^{* *}$ & $182 \pm 1.21^{*}$ \\
\hline
\end{tabular}

Values are expressed as mean \pm SEM $(n=6)$. Values are statistically significant at $* \mathrm{P}<0.05$ more significant at $* * P<0.001$ using one way ANOVA followed by Dunnet's test.

Table 4: Effect of ethanolic seed extract of Canavalia ensiformis in HFD+STZ induced rats

\begin{tabular}{|c|c|c|c|c|c|}
\hline Groups & Total cholesterol (TC) (mg/dl) & Total triglycerides (TG) (mg/dl) & HDL (mg/dl) & LDL (mg/dl) & VLDL (mg/dl) \\
\hline $\mathrm{I}$ & $86 \pm 0.6$ & $88.12 \pm 1.21$ & $36.10 \pm 1.83$ & $26 \pm 0.41$ & $14.90 \pm 0.24$ \\
\hline II & $162.23 \pm 2.8$ & $157 \pm 2.17$ & $20.28 \pm 0.88$ & $54.56 \pm 0.2$ & $31.18 \pm 1.89$ \\
\hline III & $89.78 \pm 0.12^{* * b}$ & $90.32 \pm 1.58^{* * b}$ & $30.12 \pm 0.64^{* a}$ & $41.12 \pm 0.74^{* * \mathrm{~b}}$ & $16.29 \pm 0.79 * \mathrm{a}$ \\
\hline IV & $98.42 \pm 0.68 * a$ & $99.09 \pm 2.42 * a$ & $26.15 \pm 1.87 *_{\mathrm{a}}$ & $29.43 \pm 1.64 * a$ & $22.64 \pm 1.72 * a$ \\
\hline $\mathrm{V}$ & $92.18 \pm 2.13^{* * b}$ & $94.14 \pm 0.98 * \mathrm{a}$ & $28.34 \pm 2.1^{* * \mathrm{~b}}$ & $38.71 \pm 0.98 * \mathrm{a}$ & $28.12 \pm 1.45^{* * \mathrm{~b}}$ \\
\hline
\end{tabular}

Values are expressed as mean $\pm \operatorname{SEM}(\mathrm{n}=6)$. Values are statistically significant at $* \mathrm{a}<0.05$ more significant at $* * \mathrm{~b} \mathrm{P}<0.001$ vs. hyperlipidemic control using one way ANOVA followed by Dunnet's test.
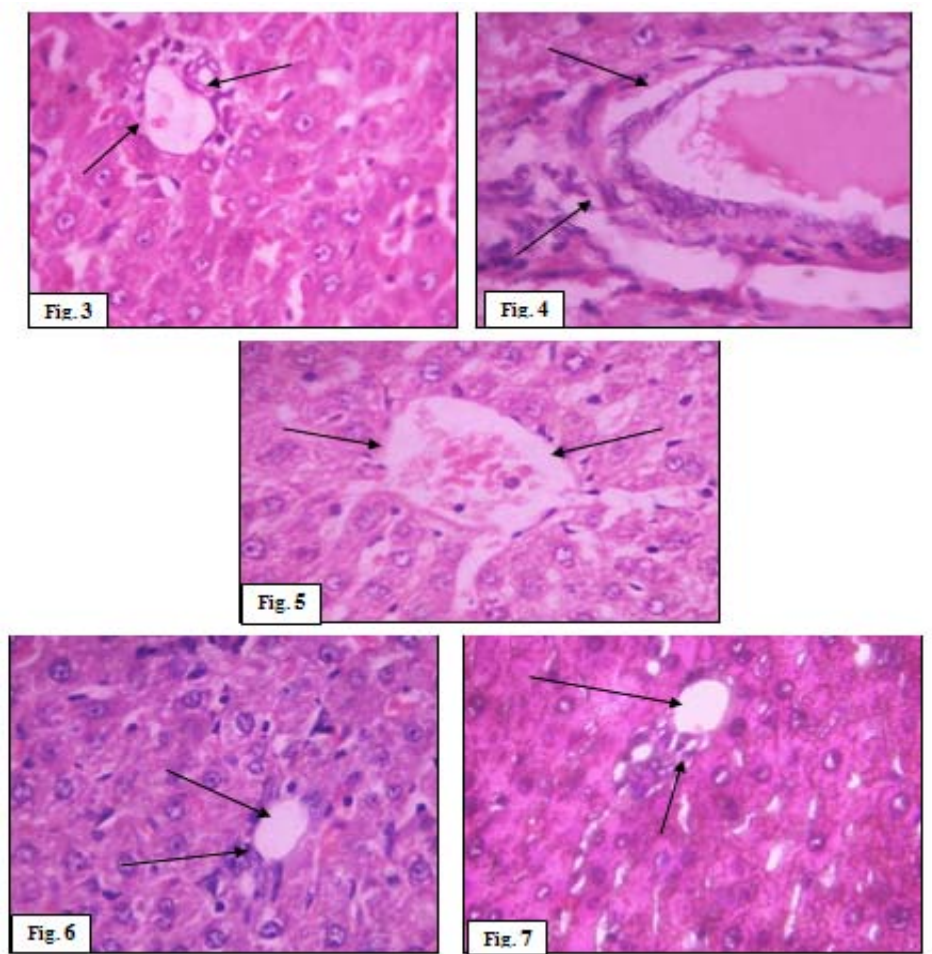

Fig. 2: Effect of EECE in HFD+STZ induced rats on different lipid levels, concentration expressed as mg/kg, Photographs of the histopathological tissue sections, fig. 3: Control group eliciting the normal liver architecture, fig. 4: Negative Control group showing the complete damage of liver architecture, fig. 5: Positive control group showing the recovery of damaged liver architecture, fig. 6: low dose treated group showing the recovery of damaged liver architecture to some extent, fig. 7: High dose treated group showing the recovery of damaged liver architecture to a significant extent 


\section{DISCUSSION}

Hyperlipidemia is related to many diseases, including obesity, hypertension, arteriosclerosis, and cancer. The ethanolic extract of seeds of Canavalia ensiformis detected the presence of flavonoids, terpenoids, saponins, proteins, alkaloids, and these chemical constituents was responsible for different therapeutic actions. Flavonoids present in the extract have been reported to decrease LDL and increase HDL, and it also helps in the removal of cholesterol from peripheral tissues to liver for catabolism and excretion. Hence, the decrease in levels of TC, TG, LDL and increase the level of HDL depicted in the present study may be due to the presence of effects of chemical constituents in EECE.

In our study, the initial attempts were directed towards finding the antihyperlipidemic potential of ethanolic extracts of seeds of Canavalia ensiformis in HFD+STZ induced diabetic rats and further sensitive for pharmacological testing. The HFD rat model with a dose of STZ (45 mg kg-1) thus can be more considered to represent the physiological path state of type 2 diabetes and was accompanied by the characteristic of hyperlipidemia condition produced by a high dose of STZ. Hence, HFD in combination with a low dose of STZ (45 $\mathrm{mg} \mathrm{kg}-1$ ) was chosen for generating the rat model for further studies. The data obtained showed that the plasma levels of TG, TC, and LDL in HFD+STZ fed rats were significantly higher than those of control group table 4. However plasma HDL levels were significantly decreased, indicating that HFD+STZ feeding caused hyperlipidemia in rats [21]. After the treatment of extract in the experimental period, it significantly decreased these changes in plasma levels of TG, TC, and LDL and increased HDL levels induced by HFD+STZ in different groups in table 4 . The EECE showed significant as the antihyperlipidemic potential at $400 \mathrm{mg} / \mathrm{kg}$ rather than $200 \mathrm{mg} / \mathrm{kg}$. So by this High-fat diet, Streptozotocin-induced model the ethanolic extract of seeds of Canavalia ensiformis has shown the significant changes in lipoprotein levels that depicts that the extract possesses the antihyperlipidemic activity.

\section{CONCLUSION}

The ethanolic extracts of seeds of Canavalia ensiformis have shown the significant potential against the hyperlipidemic condition in HFD and Streptozotocin-induced diabetic rats. Further, the characterization studies were required to know the exact mode of the mechanism of the antihyperlipidemic potential of seeds of Canavalia ensiformis.

\section{ACKNOWLEDGMENT}

Corresponding authors show gratitude towards the Chairman and Principal of Sree Vidyanikethan College of Pharmacy, A. Rangampet, Chittoor district of Andhra Pradesh for their Support and facilities provided to fulfill this research work.

\section{AUTHORS CONTRIBUTIONS}

Performed the Experiment: Kuttiappan Anitha, Ravikumar Yashoda. Wrote the paper: Kuttiappan Anitha. Revised the Article: Kuttiappan Anitha.

\section{CONFLICT OF INTERESTS}

We don't have the conflict of interest

\section{REFERENCES}

1. Amin KA, Nagy MA. Effect of carnitine and herbal mixture extract on obesity induced by high-fat diet in rats. Diabetol Metab Syndr 2009;1:17.

2. Bressani R, Gimez BR, Garcia A, Eliaz LG. Chemical composition, amino acid content and protein quality of Canavalia seeds. J Sci Food Agric 1987;40:17-23.

3. Sumner JB, Howel SF. The identification of the hemagglutinin of the jack bean with concanavalin. A J Bact 1936;32:227-37.

4. Gaydou EM, Yiano J, Bourreil PJL. Canavalia ensiformis neutral lipids, a rich source of lupeol. J A Oil Chem Soc 1992;69:495-7.

5. Mohan VR, Janardhanan K. The biochemical and nutrient assessment of less known pulses of the genus Canavalia. Int J Food Sci Nutr 1994;45:255-62.

6. Onuegbu BA, Zibokere DS, Chinah M, Ukata D. Unconventional food sources; effects of Canavalia ensiformis seeds on growth and development of domestic rats and effects of fungal infection on nutritional composition to the seeds. J D F Home Sci 1993;12:62-6.

7. Rodriguez BF, Torne SG. A chemical study of seeds in three Canavalia species. Trop Sci 1991;31:101-3.

8. Rosenthal GA, Brege MA. Catabolism of L-canavnine and 1canaline in the jack bean, Canavalia ensiformis (L.)) DC (Leguminosae). J Agric Food Chem 1989;37:591-5.

9. Vaychaudhuri M, Niyogi K, Singh M. Temporal regulation in the synthesis of concanavalin A and alpha-mannosidase in the seeds of Canavalia ensiformis. Phytochem 1988;26:3201-5.

10. Girija K, Lakshman K. Anti-hyperlipidemic activity of methanol extracts of three plants of Amaranthus in triton-WR 1339 induced hyperlipidemic rats. A Pacific J Trop Biomed 2011;1:S62-5.

11. Ghule BV, MH Ghante, AN Saoji, PG Yeole. Antihyperlipidemic effect of the methanolic extract from Lagenaria siceraria stands fruit in hyperlipidemic rats. J Ethnopharmacol 2009;124:333-7.

12. Harborne AJ. Phytochemical methods: a guide to modern techniques of plant analysis; 2008;3:4-7.

13. Kokate CK, Purohit AP, Gokhale SB. Pharmacognosy. Nirali Prakashan 2008;42:11, 56-8.

14. OECD guidelines for the testing of chemicals; 2008. Available from: http://www.oecd.org [Last accessed on 23 Mar 2006]

15. Khanna AK, Chander R, Kapoor NK, Dhawan N. Hypolipidemic activity of picroliv in albino rats. Pytother Res 1994;8:403-7.

16. Xie W, Wang W, Su H, Xing D, Cai G, Du L. Hypolipidemic mechanisms of Ananas comosus L. leaves in mice: different from fibrates but similar to statins. J Pharmacol Sci 2007;103:267-74.

17. Thirunavukkarasu Tirumala, Narayanaswamy Tamilselvan, Ernest David. Hypolipidemic activity of Piper betel in high-fatdiet-induced hyperlipidemic rat 2014;3:131-5.

18. Lopes Virella MF, Stone P, Ellis S, Colwell JA. Cholesterol determination in high-density lipoproteins separated by three different methods. Clin Chem 1977;23:882-4.

19. Carr TP, Andresen CJ, Rudel LL. Enzymatic determination of triglyceride, free cholesterol, and total cholesterol in tissue lipid extracts. Clin Biochem 1993;26:39-42.

20. Weggemans RM, Trautwein EA. Relation between soy-associated isoflavones and LDL and HDL cholesterol concentrations in humans: a meta-analysis. Eur J Clin Nutr 2003;57:940-6.

21. Aziz Sahid, Gohain Kalpana. A study of the hypolipidemic and antioxidant activities of whole plant extracts of ipomoea aquatica fork in experimentally induced hyperlipidemia in rabbits. Int J Pharm Pharm Sci 2016;10:265-9. 